\title{
NEGATIO NON COGNOSCITUR NISI PER AFFIRMATIONEM: SOME REMARKS ON NEGATION PARASITISM IN JOHN DUNS SCOTUS'S WRITINGS
}

\begin{abstract}
Keywords: John Duns Scotus, Negation, Asymmetrical Account of Negation, Negation Parasitism, Negation Eliminativism
\end{abstract}

\section{John Duns Scotus's Asymmetrical Account of Negation}

According to Laurence Horn, philosophical inquiries about the topic of negation can be sorted into two main groups: symmetricalist and asymmetricalist accounts. Given a couple of negatively opposed elements of any kind, such as "man" and "not-man" or 'a man is an animal' and 'a man is not an animal' etc., symmetricalist accounts of negation would grant the same dignity to both the extremes, not acknowledging any priority in time, dependence

* Matteo Maserati-PhD Student at RAMUS (Ricerche e Studi sull'Antichità, il Medioevo, l'Umanesimo-Salerno), University of Salerno, Italy. His main research themes are logic, philosophy of language, epistemology and metaphysics in the field of the history of medieval philosophy, with a major focus on the figure of John Duns Scotus.

Address for correspondence: Dipartimento di Scienze del Patrimonio Artistico e Culturale, Università degli Studî di Salerno, via Giovanni Paolo II, 132, 84084 Fisciano (SA), Italy. E-mail: matteo.maserati00@gmail.com. 
or meaning to either of them. Asymmetricalist accounts would instead bestow a kind of priority, marking one of the extremes, usually the positive one, as paramount. The latter position tends therefore to understand the negative element as "parasitic" or dependent on the positive, independent element. Moreover, a stronger kind of asymmetricalism is concerned with the "elimination" of the negative element through a process of reduction to its positive counterpart, endorsing for instance that the world and its facts can be described only through positive language. ${ }^{1}$ Employing Horn's terminology, this paper aims to assess some theological and epistemic consequences of John Duns Scotus's asymmetrical or parasitic account of negation. Specifically, it will be shown (i) that Scotus endorses some asymmetricalist general theses and (ii) how this asymmetricalism is radically applied in his conception of the theological inquiry. In Ordinatio, lib. I, d. 3, in fact, he develops two different strategies to delegitimize negative theology by reducing it to its cataphatic counterpart. It will be also shown how the first strategy in particular can be widened over the scope of theology, marking a claim for general epistemology.

Asymmetricalism constitutes the most common approach to negation throughout the history of western philosophy, given also the many shades it can assume. ${ }^{2}$ Horn provides a useful historical survey which notes how Aristotle's position ranges from asymmetricalism to symmetricalism, ${ }^{3}$ as several

${ }^{1}$ Horn, 2001, pp. 45-79.

${ }^{2}$ Horn provides a list of nine theses that characterise an asymmetrical account of negation: each of these is a sufficient condition to mark an account as asymmetrical, while their possible cumulation determines the kind and the strength of the whole account as it is. The nine theses are: "(i) affirmation is logically prior, negation secondary; (ii) affirmation is ontologically prior, negation secondary; (iii) affirmation is epistemologically prior, negation secondary; (iv) affirmation is psychologically prior, negation secondary; (v) affirmation is basic and simplex, negation complex; (vi) affirmation is essential, negation eliminable; (vii) affirmation is objective, negation subjective; (viii) the affirmative sentence describes a fact about the world, the negative sentence a fact about the affirmative; (ix) In terms of information, the affirmative sentence is worth more, the negative worth less (if not worthless).” Horn, 2001, pp. 45-46.

${ }^{3}$ Horn, 2001, p. 44: "Included in the asymmetricalist faction as leaders, proselytizers, acolytes and camp followers are Parmenides, Plato, Aristotle (sometimes), Saint Thomas Aquinas, Kant, Goethe, Hegel, Bergson, the neo-Hegelian idealists, Russell (usually), Strawson, Tesnière, Givón, and a variety of psycholinguists; the symmetricalist camp claims Aristotle (sometimes), Frege, Royce, Russell (occasionally), Wittgenstein (perhaps), Ayer and Geach. It will be observed that the two pivotal figures in 
textual passages from his Organon and Metaphysics witness. For instance, the call for symmetricalism can be found in the Prior Analytics, where the Stagirite points out that to any positive assertion, a negative one is correlated. ${ }^{4}$ The accordance with an asymmetrical account is instead expressed in some passages from the Posterior Analytics, ${ }^{5}$ where the epistemic priority of the positive pole is formulated, and from the Metaphysics, ${ }^{6}$ where is granted a higher degree in knowing what something is, rather than in knowing what something is not. In the commentaries on the Aristotelian writings, Scotus intercepts both claims. In his second work on the Perihermeneias, for instance, it is considered evident that "cuiuslibet unius affirmationis est una negatio," " which matches perfectly with the Aristotelian symmetricalist thesis marked by Horn. However, the littera shows how the asymmetrical account is favored by the Subtilis. Within the same commentary, in fact, negation is generally understood through the concept of "remotion" 8 and usually grounded in a positive element:

the history of negation, Aristotle and Russell, stand astride the field with one foot in each camp."

${ }^{4}$ Aristotle, Prior Analytics, I.46, 51 b 35 (ed. Barnes, 1984, p. 54): "Therefore it is clear that 'it is not-good' is not the denial of 'it is good'. If then of every single thing either the affirmation or the negation is true if it is not a negation clearly it must in a sense be an affirmation. But every affirmation has a corresponding negation. The negation then of this is 'it is not not-good'."

${ }_{5}$ Aristotle, Posterior Analytics, I.25, 86b 30-38 (ed. Barnes, 1984, pp. 35-36): “Again, if the universal immediate proposition is a principle of deduction, and the universal proposition is affirmative in the probative demonstration and negative in the negative, and the affirmative is prior to and more familiar than the negative (for the negation is familiar because of the affirmation, and the affirmation is prior, just as being the case is prior to not being the case) - hence the principle of the probative is better than that of the negative; and the one which uses better principles is better."

${ }^{6}$ Aristotle, Metaphysics, III.2, 996b 14-16 (ed. Barnes, 1984, p. 30): “[...] the science of substance must be of the nature of wisdom. For as men may know the same thing in many ways, we say that he who knows what a thing is by the characteristics it has knows more fully than he who knows it by the characteristics it has not, and in the former class itself one knows more fully than another, and he knows most fully who knows what a thing is, not he who knows its quantity or quality or what it can by nature do or have done to it [...]."

${ }^{7}$ Iohannes Duns Scotus, Quaestiones in duos libros Perihermeneias, pars II, qq. 6-9, n. 7 (ed. Etzkorn et al., 2004, p. 208).

8 Iohannes Duns Scotus, Quaestiones in duos libros Perihermeneias, pars I, q. 4, n. 2 (ed. Etzkorn et al., 2004, p. 157): "Item, 'negatio alicuius est remotio alicuius ab 
Verbum aggregatur ex duobus, ex re scilicet et compositione qua significatur aliquid esse vel non esse. Verbum autem infinitum fit per additionem negativae particulae, quae removet verbum secundum se. Cum igitur additur nomini, removet quod significatur per verbum 'esse' de alio. Non autem ob aliud est propositio negativa nisi quia removetur aliquid de esse ad non esse. Igitur verbum infinitum est verbum intellectum cum negatione, quod non accidit ex parte nominis. ${ }^{9}$

Being the result of a remotion, any negation relies on an already given element and marks a shift towards the non esse. In the commentaries on the Metaphysics, this approach is made even more explicit. Before remarking that any affirmation is better known than its correspondent negation, Scotus states in fact that 'bonum non est malum', a negation, is true only because 'bonum est bonum', a positive assertion, is true. ${ }^{10} \mathrm{~A}$ further application of this claim is found in Metaphysics, IV where an adnotation marks how the principle of non contradiction, modally expressed as 'impossibile est idem simul esse et non esse', can be inferred by two affirmative tautological premises, namely 'ens est ens' and 'non-ens est non-ens'. Given those, in fact, it would be possible to conclude that 'non est idem ens et non-ens', understood as equivalent to the modal form at stake. ${ }^{11}$ From these positions expressed in the commentaries on Aristotle, at least three asymmetricalist theses can be

aliquo'; igitur negatio adveniens homini aliquid ab eo removet; et si hoc, aliquid tollit et aliquid derelinquit; [...]."

${ }^{9}$ Iohannes Duns Scotus, Quaestiones in duos libros Perihermeneias, pars II, q. 1, n. 10 (ed. Etzkorn et al., 2004, p. 195).

${ }^{10}$ Iohannes Duns Scotus, Quaestiones super librum Metaphysicorum Aristotelis, lib. II, qq. 2-3, n. 55 (ed. Etzkorn et al., 1997, p. 217): "Item, omni propositione negativa prior est affirmativa, II Perihermeneias, cap. ultimo. Haec enim ‘bonum non est malum' est vera, quia haec affirmativa prior est vera 'bonum est bonum'. Et Philosophus IV huius: "notior utique erit dictio quam opposita negatio" [...]."

${ }^{11}$ Iohannes Duns Scotus, Quaestiones super librum Metaphysicorum Aristotelis, lib. IV, q. 3, n. 36, adnotatio interpolata (ed. Etzkorn et al., 1997, p. 375): "Nota quod aliter posset probari quod non sit istud principium primum simpliciter in complexis 'impossibile est idem simul esse et non esse'. Tum quia est propositio negativa, quod patet ex suis oppositis quae sunt affirmativae: 'contingit idem simul esse et non esse' et 'necesse est idem simul esse et non esse'. Nulla autem propositio negativa est simpliciter prima, in fine II Perihermeneias. Sed omnis talis reducitur ad affirmativam priorem. Tum quia ista propositio potest concludi ex prioribus propositionibus syllogistice sic: 'ens est ens, et non-ens est non-ens, ergo non est idem ens et non-ens', vel 'impossibile est idem simul esse et non esse'. [...]." 
inferred: (i) negative expressions are not syntactically independent, since they are the result of the application of a negative particle to other linguistic elements from which they remove something; (ii) negative assertions are not semantically independent, since their truth-value depends on the truthvalues of other positive assertions; (iii) negative assertions are epistemically weaker than positive ones.

A fourth thesis can be found in the theological writings, where Scotus resorts to the recurrent expression aliquid positivum to deal with negation in metaphysical frames, involving also major topics such as individuation or matter. ${ }^{12}$ In these contexts, Scotus argues that negation cannot constitute any positive being (entitas) since not only it requires a positive grounding, but also it does not bestow any degree of perfection upon the being to which it is applied..$^{13}$ This introduces therefore another asymmetry claim, namely that (iv) negations are ontologically weak, since negative properties fails in bestowing any ontological perfection to its subject. Having assessed that Scotus's asymmetricalism involves at least four theses, we can address the specifical theological arguments.

\section{The First Strategy to Deal with Negation in Theology: An Elimination Scheme}

The first part of Ordinatio, lib. I, d. 3 is devoted to a theological and epistemic inquiry, namely the possibility for the human intellect to know God. Differently from the parallel section of the Lectura, however, in this writing Scotus introduces the first two questions with a series of preliminary statements. The very

12 About Duns Scotus's conception of matter: Duba, 2005; King, 2003; Pasnau, 2011.

13 Iohannes Duns Scotus, Lectura, lib. II, d. 3, p. 1, qq. 1-2, n. 50 (ed. Modrić et al., 1982, p. 243): "Praeterea, numquam per negationem constituitur entitas, nam negatio semper praesupponit aliquid positivum in quo fundetur; si igitur prima substantia non habet nisi naturam et negationem duplicem, et ista negatio non addit perfectionem supra naturam, sequitur quod prima substantia non dicet maiorem perfectionem quam substantia secunda, - quod falsum est, quia 'prima substantia maxime et proprie dicitur', sicut dicit librum praedicamentorum." 
first element of this list is utterly relevant for the topic of negation since its interpretation leads towards an assessment of eliminativism: ${ }^{14}$

In prima quaestione non est distinguendum quod Deus possit cognosci negative vel affirmative, quia negatio non cognoscitur nisi per affirmationem, II Perihermeneias in fine et IV Metaphysicae. Patet etiam quod nullas negatione cognoscimus de Deo nisi per affirmationes, per quas removemus alia incompossibilia ab illis affirmationibus. ${ }^{15}$

The first question at stake asks whether God can be known naturally by the intellect of a still living human being (viator), and the quoted text cuts a most problematic knot for the medieval tradition, namely the distinction between a negative kind of theology, concerned with knowing what God is not, and a positive one. ${ }^{16}$ Scotus's claim is neat: discerning between a positive and a negative theological approach is irrelevant, since the asymmetrical account of negation holds independently to the specific object of knowledge. According to this, each negatively expressed knowledge that human beings can reach about God depends ultimately on a precedent and affirmative knowledge about that same object. The formulation that follows the Aristotelian claim suggests a schematic way to eliminate negative propositions resorting to a conditional. Scotus writes in fact that any negative knowledge about God depends on a different positive knowledge, to which the former removes what is incompossible with the latter. For instance, we can take the paradigmatic sentence 'God is not a stone' and suppose that it is renownedly true. According to the quoted text, if we know that 'God is not a stone', then we are required to know that God is something, and then to assess that 'being a stone' marks an incompossible propriety with what we already knew about God. We can translate this example in a semi-formal expression, where ' $A$ ' and ' $\mathrm{B}$ ' stand generically for two different predicables:

${ }^{14}$ As already mentioned, "elimination" marks a strong kind of asymmetricalism which refuses to assign any independence to the negative elements in a specific context, resulting in strategies that aim to reduce such negative elements to other positive ones.

15 Iohannes Duns Scotus, Ordinatio, lib. 1, d. 3, p. 1, qq. 1-2, n. 10 (ed. Balić et al., 1954, p. 4).

${ }^{16}$ For more on the position held by Scotus on the topic of positive, negative and superlative theology, see Cezar, 2008; Mann, 2003; Ninci, 1995; Schönberger, 1996. 
If I know 'God is not A' then I know 'God is $\mathrm{B}$ and $\mathrm{A}$ is incompossible with B'

Two questions arise immediately from this formulation, namely whether such an attempt is effectively sustained by Scotus's philosophical and theological frame, and whether this scheme can be generalized and applied in any epistemic context, substituting the specific subject 'God', which marks a most peculiar object of knowledge, with a generic one. To assess the consistency of this scheme, we need to assume the antecedent as true and then try to assess the truth of the conjunction in the consequent. Hence, at least two questions must be answered, namely (i) what can be predicated about God in a positive manner and (ii) what it means that a predicable is incompossible with another.

\section{(ia) Suitable Predicates for God: Infinity}

In Ordinatio, lib. I, d. 2, Scotus faces the problem of understanding and defining the notion of 'infinite'. Even though the strict closeness between the ideas of God and infinity is standard within the medieval tradition, Scotus's speculative assumptions and gains are not without innovation. Specifically, he endorses a positive conception of infinity, establishing a critical dialogue with other authors, mainly Henry of Ghent. ${ }^{17}$ About this, the first and second questions of d. 2 call, respectively, for the existence and intelligibility of an actual infinite being. God is explicitly involved: to the Subtilis, asking about the intelligibility of an infinite being is in fact the same as asking how we know that God exists. ${ }^{18}$ Scotus also states that even if it is not possible to provide a propter quid proof for the existence of the divine, infinite being, a demonstration quia is feasible at any rate. Starting from this, he produces a famous argument in natural theology, displayed almost identically in the Tractatus de primo principio, ${ }^{19}$ by which God is identified with the first efficient cause, the ultimate final cause and the most eminent being.

17 Biard, 2004, pp. 388-389.

18 Iohannes Duns Scotus, Ordinatio, lib. I, d. 2, p. 1, qq. 1-2, nn. 1, 10 (ed. Balić, et al., 1950, pp. 125, 128, 131): "Utrum in entibus sit aliquid existens actu infinitum [...] Utrum aliquod infinitum esse sit per se notum, ut Deum esse [...] Primo respondeo ad secundam quaestionem, quae inquirit de modo cognoscendi istam 'Deus est'."

19 About Scotus's proof, see Flores, 2000; Ross, Bates, 2003. 
Furthermore, Scotus states that the most proper connotation for the divine principle is precisely infinity, either in power, intellect, or magnitude. For what concerns the human understanding of God, therefore, 'infinite being' is the best expression to describe it. ${ }^{20}$ Therefore, and for our current aim, 'infinite' must be considered as a suitable predicate to occur in 'God is B'.

This speculation about God as the positively infinite being is furtherly developed in Ordinatio, lib. I, d. 3, where it gets intertwined with the univocist account of predication endorsed by the Author, a topic about which many studies have been produced. ${ }^{21}$ The elaboration of this univocist account in the comments on the Sententiae is mainly motivated by theological reasons, since it allows Scotus to explain how it is possible for humans, despite being in via, to have a concept of God by which the divine being is understood per se et quiditative..$^{22}$ In the same passages, the Subtilis provides his famed connotation of 'univocal concept' as a concept "which is so unified that its unity is enough for a contradiction in affirming and denying it of the same subject" and for which this unity "is also enough to play the part of a middle term in a syllogism." ${ }^{23}$ Relatively to the concept human beings can have about God, the theme of infinity is once again reintroduced, however, more radically: even if now Scotus considers several concepts that can be grasped about God, in fact, he declares that the most perfect and simple available

${ }^{20}$ Iohannes Duns Scotus, Ordinatio, lib. I, d. 2, p. 1, qq. 1-2, nn. 145-147 (ed. Balić, et al., 1950, pp. 213-215): "Ex dictis patet solutio quaestionis. Nam ex primo articulo habetur quod aliquod ens exsistens est simpliciter primum triplici primitate, videlicet efficientiae, finis et eminentiae, et ita simpliciter quod incompossibile est aliquid esse prius. Et in hoc probatum est esse de Deo quantum ad proprietates respectivas Dei ad creaturam vel in quantum determinat dependentiam respectus creaturarum ad ipsum. Ex secundo articulo habetur quadruplex via quod illud primum est infinitum: primo videlicet quia primum efficiens, secundo quia primum cognoscens omnia factibilia [...], tertio quia finis ultimus, quarto quia eminens. [...] Ex praemissis conclusionibus, probatis et ostensis, arguitur sic ad quaestionem: aliquod ens tripliciter primum in entibus exsistit in actu; et illud tripliciter primum est infinitum; ergo aliquod infinitum ens exsistit in actu. Et istud est perfectissimum conceptibile et conceptus perfectissimus, absolutus, quem possumus habere de Deo naturaliter, quod sit infinitus, sicut dicetur distinctione 3. Et sic probatum est Deum esse quantum ad conceptum vel esse eius, perfectissimum conceptibilem vel possibilem haberi a nobis de Deo."

${ }^{21}$ For instance: Dumont, 1998; Hoffman, 2013; Pasnau, 2011; Pini, 2005.

${ }^{22}$ Iohannes Duns Scotus, Ordinatio, lib. I, d. 3, p. 1, qq. 1-2, nn. 25-26 (ed. Balić et al., 1954, pp. 16-18).

${ }^{23}$ King, 2003, p. 58. 
to human intellect is that of infinite being. Scotus believes in fact that this concept is even more simple than the transcendental predicates, because while "good", "true" and so on are fully-fledged predicates, "infinity" is understood as an intrinsic mode of being. Specifically, the Subtilis argues that the concept of infinity bestows on its apparent subject the highest possible degree of perfection, which is positively infinite, and thus he understands the whole expression ens infinitum not as a composition of subject and predicate such as ens bonum, but rather as authentically simple. ${ }^{24}$ Therefore, and to our current aim, rather than asserting that 'God is infinite', as the conclusions of the former distinction had suggested, a more precise formulation would be 'God is the infinite being' or 'God is being at its highest degree of perfection', because it is clear that Scotus is concerned to make a distinction between simple predicates and infinity as a mode.

\section{(ib) Suitable Predicates for God: Transcendentals}

Transcendentals can surely be predicated of God; anyway, the traditional concepts of unum, verum, bonum do not saturate the class of transcendental concepts as conceived by Scotus. Over than extending the status of transcendental to disjunctive properties ${ }^{25}$ in fact, the Subtilis sets the condition

${ }^{24}$ Iohannes Duns Scotus, Ordinatio, lib. I, d. 3, p. 1, qq. 1-2, n. 58 (ed. Balić et al., 1954, p. 40): “Quarto dico quod ad multos conceptus proprios Deo possumus pervenire, qui non conveniunt creaturis - cuiusmodi sunt conceptus omnium perfectionum simpliciter, in summo. Et perfectissimus conceptus, in quo quasi in quadam descriptione perfectissime cognoscimus Deum, est concipiendo omnes perfections simpliciter et in summo. Tamen conceptus perfectior simul et simplicior, nobis possibilis, est conceptus entis infiniti. Iste enim est simplicior quam conceptus entis boni, entis veri, vel aliorum similium, quia 'infinitum' non est quasi attributum vel passio entis, sive eius de quo dicitur, sed dicit modum intrinsecum illius entitatis, ita quod cum dico 'infinitum ens', non habeo conceptum quasi per accidens, ex subiecto et passione, sed conceptum per se subiecti in certo gradu perfectionis, scilicet infinitatis,- - sicut albedo intensa non dicit conceptum per accidens sicut albedo visibilis, immo intensio dicit gradum intrinsecum albedinis in se. Et ita patet simplicitas huius conceptus 'ens infinitum'."

25 Iohannes Duns Scotus, Ordinatio, lib. I, d. 8, p. 1, q. 3, n. 115 (ed. Balić et al., 1956, pp. 206-207): "Hoc patet ex alio, quia ens non tantum habet passiones simplices convertibiles - sicut unum, verum et bonum — sed habet aliquas passiones ubi opposita distinguuntur contra se, sicut necesse esse vel possibile, actus vel potentia, et huiusmodi. Sicut autem passiones convertibiles sunt transcendentes quia consequuntur ens in quantum non determinatur ad aliquod genus, ita passiones disiunctae sunt transcendentes [...]." 
for transcendentality not in the coextensivity with the concept of being as such, but rather in the fact that the concept of being must be the only superior predicate to the transcendental at stake. ${ }^{26}$ Because of this, some transcendentals might not be suitable for being predicated of everything. This is the case of absolute perfections ${ }^{27}$ (perfectiones simpliciter) which, according to the Lectura, are nothing but all the perfections that the divine nature instantiates:

[...] quidquid est in essentia divina, est perfectionis simpliciter. Sed 'perfectio simpliciter' est talis perfectio quae in quolibet 'melius est ipsum quam non ipsum', quod intelligendum est respectu cuiuslibet sibi incompossibilis; et ideo licet sapientia sit perfectionis simpliciter, non tamen melius est cani esse sapiens, quia destruit naturam; unde illud est simpliciter perfectionis quod in quolibet melius est quolibet sibi incompossibili. ${ }^{28}$

In Ordinatio, lib. I, d. 3 it is also evident how absolute perfections fall in the sway of Scotus's univocism. It is in fact stated that there must be a common ground for creatural and divine perfections, since accepting the existence of strictly creatural or strictly divine perfections would lead to controversies. Such common ground is marked as a ratio communis Deo et creaturae, which allows Scotus's metaphysics to proceed smoothly from the formal ratio of creatural perfection to the divine one: thanks to univocism, in fact, the formal ratio is always kept the same and only its degree of perfection changes, being limited and partial for the creatures, highest for God. ${ }^{29}$ Examples of this absolute perfections are the intellect and the will.

\section{${ }^{26}$ Alliney, 2012, p. 64.}

27 Iohannes Duns Scotus, Ordinatio, lib. I, d. 8, p. 1, q. 3, n. 115 (ed. Balić et al., 1956, pp. 206-207): "[...] Ita etiam potest sapientia esse transcendens, et quodcumque aliud, quod est commune Deo et creaturae, licet aliquod tale dicatur de solo Deo, aliquod autem de Deo et aliqua creatura. Non oportet autem transcendens, ut transcendens, did de quocumque ente nisi sit convertibile cum primo transcendente, scilicet ente."

${ }^{28}$ Iohannes Duns Scotus, Lectura, lib. I, d. 2, p. 2, qq. 1-4, n. 250 (ed. Balić et al., 1966, p. 208).

29 Iohannes Duns Scotus, Ordinatio, lib. I, d. 3, p. 1, qq. 1-2, nn. 38-39 (ed. Balić et al., 1954, pp. 25-26): "Item, quarto, potest sic argui: aut aliqua 'perfectio simpliciter' habet rationem communem Deo et creaturae, et habetur propositum, aut non sed tantum propriam creaturae, et tunc ratio eius non conveniet formaliter Deo, quod est inconveniens; aut habet rationem omnino propriam Deo, et tunc sequitur quod nihil 
Lastly, two classes of predicates are positively suitable for God: the simple concept of "infinite being" and any transcendental concept, either "traditional" or absolute perfections. Instances of those possibilities are then 'God is an infinite being', 'God is one or true or good', 'God is intelligent or rational', 'God is willing'.

\section{(ii) The Relation of Incompossibility between Predicates}

Moving now to the second element of the conjunction, ' $\mathrm{A}$ is incompossible with B', we need to understand the meaning of incompossibility which, as shown, it is also essential to define what absolute perfections are. Incompossibility is not a simple or monadic predicate but a relation that involves two different predicables. Moreover, the analysis of this relation usually occurs in passages where Scotus develops modal concepts, ${ }^{30}$ strongly linked with the concepts of impossibility and possibility. ${ }^{31}$ The root for incompossibility can be found in the seemingly primitive concept of repugnantia, which marks a form of incompatibility between either terms or natures. In a question devoted to the theme of divine power, for instance, Scotus presents a definition of logical power as non repugnantia terminorum and extends it to the effective natural power of generation available to the trinitarian God. According to the logical definition, it is concluded that for God as the Father it is possible to generate, while for God as either the Son or the Holy Ghost such an act is impossible. The thesis is argued as such: since the terms "Father" and "generation" are not "repugnant" to each other, while the terms "Son" or "Holy Ghost" and "generation" are, then the definition of the logical power compels the assignation of the positive modal to the Father, the negative to the other Persons. ${ }^{32}$ In the forty-third distinction of both Lectura

attribuendum est Deo [...] Confirmatur etiam haec quarta ratio sic: omnis inquisitio metaphysica de Deo sic procedit, considerando formalem rationem alicuius et auferendo ab illa ratione formali imperfectionem quam habet in creaturis, et reservando illam rationem formalem et attribuendo sibi omnino summam perfectionem, et sic attribuendo illud Deo. Exemplum de formali ratione sapientiae (vel intellectus) vel voluntatis [...]. Ergo omnis inquisitio de Deo supponit intellectum habere conceptum eundem, univocum, quem accepit ex creaturis."

30 Some references for Scotus's modal theory are: King, 2001; Normore, 2003.

31 Mondadori, 2004, p. 327.

32 Iohannes Duns Scotus, Ordinatio, lib. I, d. 7, q. 1, n. 27 (ed. Balić et al., 1956, p. 118): "Uno enim modo dicitur 'potentia logica', quae dicit modum compositionis factae 
and Ordinatio, then, it is possible to find a connotation of absolute impossibility (simpliciter impossibile) according to which an object is absolutely impossible only if it is intrinsically incompatible or repugnant with existence, such as a chimera. Impossibility is treated as an entirely formal matter, since it does not involve any other element over the nature of the object itself, while possibility is just its specular and positive equivalent, expressed by the concepts of compatibility or non-repugnance. To exemplify this purely formal conception of impossibility, Scotus presents an analogy resorting to the opposite predicates of "black" and "white". Neither of them is an absolute impossible thing, since white things and black things can exist, yet they are intrinsically incompossible one with the other, regardless of the substances to which they might inhere as properties. ${ }^{33}$ The example of black and white, however, still fails in conveying a precise meaning to the relation of incompossibility as such. In the same distinction, Scotus explains that to be incompossible one to the other, two elements must satisfy the precondition of being possible in themselves, which entails that an absolute impossible being cannot be compossible or incompossible to anything else. Assumed the intrinsic possibility of two given things, then, those are incompossible one to the other only if (i) they cannot constitute a unitary being and only if (ii) they cannot produce a third element distinguished from them both. ${ }^{34}$ Without relying on the relation of contrariety, this development explains far

ab intellectu, - et ista notat non-repugnantiam terminorum [...]. Et si hoc modo quaeratur de 'potentia' in divinis, dico quod ipsa est, comparando generationem ad quemcumque actum non-repugnantem generationi: et tunc potentia, vel possibilitas, est Patris vel Dei ad hoc praedicatum quod est generare, quia isti termini non repugnant; impossibilitas autem est quod Filius vel Spiritus Sanctus generent, quia isti termini repugnant."

${ }^{33}$ Iohannes Duns Scotus, Ordinatio, lib. I, d. 43, q. unica, n. 5 (ed. Balić et al., 1963, p. 353): "Nihil est simpliciter impossibile nisi quia simpliciter repugnat sibi esse; cui autem repugnat esse, repugnat ei ex se primo, et non propter respectum aliquem affirmativum vel negativum eius ad aliquid aliud primo [...] sicut album et nigrum per se ex suis rationibus formalibus contrariantur et habent repugnantiam formalem, circumscribendo per impossibile omnem respectum ad quodcumque aliud. [...] possibile, secundum quod est terminus vel obiectum omnipotentiae, terminus vel obiectum omnipotentiae, est illud cui non repugnat esse et quod non potest ex se esse necessario."

${ }^{34}$ Iohannes Duns Scotus, Ordinatio, lib. I, d. 43, q. unica, n. 16 (ed. Balić et al., 1963, p. 359): “[...] Quod intelligo sic: 'impossibile simpliciter' includit incompossibilia, quae ex rationibus suis formalibus sunt incompossibilia, et ab eo sunt principiative incompossibilia, a quo principiative habent suas rationes formales. Est ergo ibi iste processus, quod sicut Deus suo intellectu producit possibile in esse possibili, ita producit duo entia 
better why black and white are incompossible properties. It is also evident that the relations of incompossibility and compossibility are symmetrical, so if ' $\mathrm{A}$ ' is compossible or incompossible to ' $\mathrm{B}$ ', the opposite holds as well. ${ }^{35}$

According to this, the quoted example from the Lectura where Scotus marked the incompossibility between the absolute perfection of sapientia and the canine nature is totally sound. Since every dog is an irrational animal, in fact, its nature is incompossible with the rational requirements of intellectual knowledge, and therefore not only it cannot be better for a dog to be sapiens, but it is formally or intrinsically impossible for any dog to be it.

\section{Assessing the Soundness of the Scheme}

There are now enough elements to test the soundness of the eliminative conditional. Let's take the negative sentence 'God is not a dog' as an instance. In order to eliminate the negation, we introduce the eliminative conditional, obtaining: if it is known that God is not a dog, then it is known that God is rational and that the predicable "dog" is incompossible with the predicate "rational"; the antecedent is assumed to be true and the consequent is proven by the characterization of absolute perfections and the univocist account of predication. Moreover, the same strategy can be effectively applied to any term that stands for an inanimate being, such as the paradigmatic stone. It is also evident that the "traditional" transcendental concepts are hardly useful in this process: they are in fact predicable of everything and their occurrence in the relation of incompossibility will therefore be irrelevant. It is also clear that the opposite verse of the conditional holds, and this is because: if I know that God is a rational being and I know that

formaliter (utrumque in esse possibili), et illa 'producta' se ipsis formaliter sunt incompossibilia, ut non possint simul esse unum, neque aliquid tertium ex eis; [...]."

35 I am aware of the fact that talking about 'symmetrical relations' is anachronistic in this milieu, since it requires us to understand relations as types and polyadic predicates (Marenbon, 2016, pp. 534-535). The standard realistic conception of relations in the late 13 th century, instead, understands them as tokens, specifically conceiving each relation as an accident grounded in an element and pointing towards another one (Mugnai, 2016, pp. 534-535). Scotus is no exception in that; therefore, when I state that ' $\mathrm{A}$ is incompossible to $\mathrm{B}$ ' is symmetrical, I simply mean that its inverse, namely ' $\mathrm{B}$ is incompossible to A', holds as well. For the same reason, I chose to keep this formulation instead of 'A and B are incompossible' which, despite being more intuitive, could be misleading. 
being rational is incompossible with being a dog, then I know that God is not a dog, since the concept of God falls in the extension of "rational being", while the concept of "dog" does not at all. ${ }^{36}$

A strategy only based on absolute perfections, however, finds some difficulties in dealing with the case of intelligent and willing beings such as humans or angels, since those creatures are compossible with a few of the absolute perfections and instantiate them. To deal with these cases, we can resort to the concept of ens infinitum, because it notes a neat demarcation between divine and creatural being, as the following passage witnesses:

Secundo sic: ens videtur sufficienter dividi-tamquam in illa quae includunt ipsum quiditative - in ens increatum et in decem genera, et in partes essentiales decem generum; saltem non videtur habere plura dividentia quiditative, quidquid sit de istis. Igitur si 'unum' vel 'verum' includant quiditative ens, continebitur sub aliquo istorum. Sed non est aliquod decem generum, patet,- - ne ex se est ens increatum, quia convenit entibus creatis; igitur esset species in aliquo genere vel principium essentiale alicuius generis: sed hoc est falsum, quia omnis pars essentialis in quocumque genere, et omnes species cuiuscumque generis, includunt limitationem, et ita quodcumque transcendens esset de se finitum, et per consequens repugnaret enti infinito, ne posset dici de ipso formaliter, quod est falsum, quia omnia transcendentia dicunt 'perfectiones simpliciter' et conveniunt Deo in summo. ${ }^{37}$

The incompatibility between the finite and the infinite being, depending on the distinction between increate and creatural being, is hence stated. This repugnance allows us to solve the cases for 'God is not a human' or 'God is not an angel', both of which hold because God is the infinite being, and the simple concept "being infinite" is incompatible with any kind of finite

${ }^{36}$ A relation of incompossibility entails, by definition, that it is impossible for its extremes to produce anything unitary altogether. According to this, the extremes at stake cannot be predicated one of the other. Assuming that "dog" and "rational" are incompossible, therefore, the sentence 'a dog is rational' will be contravalid, while its opposite 'a dog is not rational' will be always true. The scheme for our already proven conditional is: 'if God is not A then (God is B and A is incompossible to B)'. Inverting this, we obtain: ' $i f$ (God is $\mathrm{B}$ and $\mathrm{A}$ is incompossible to $\mathrm{B}$ ) then God is not $\mathrm{A}$ '. In our case, A - " $\operatorname{dog}$ "- , is incompossible to $\mathrm{B}$ - "being rational"-, therefore it is always true that 'A is not B'. Also, we assume that God is B, therefore we can conclude that God is not A.

${ }^{37}$ Iohannes Duns Scotus, Ordinatio, lib. I, d. 3, p. 1, q. 3, n. 135 (ed. Balić et al., 1954, p. 84). 
being, namely with any creatural aspect that necessarily belong to one of the ten Aristotelian categories.

\section{Extending the First Strategy from Theology to General Epistemology}

We will now try to generalize the original conditional scheme, extending it beyond the scope of theological inquiry. To do so, the term denoting God will be substituted with a general predicable, resulting in the following formulation:

If $\mathrm{I}$ know ' $\mathrm{C}$ is not $\mathrm{A}$ ' then $\mathrm{I}$ know ' $\mathrm{C}$ is $\mathrm{B}$ and $\mathrm{A}$ is incompossible to $\mathrm{B}$ '

Although we could not find any explicit instance of this general formulation, there are nonetheless some textual passages to which the scheme can be applied. Already quoted is a passage from the questions on the Metaphysics where Scotus states the dependence of the negative sentence bonum non est malum on the positive one bonum est bonum. The passage belongs to a question that asks whether the human intellect in via can grasp a kind of knowledge about immaterial substances, and more precisely to a section in which Scotus provides arguments against a thesis that denies such an ability in humans. According to the opposing thesis, there are only two possible ways for the human intellect to know and understand immaterial substances: either through a quia kind of knowledge, or negatively, which means that humans can only know what the immaterial substances are not (quid non sunt). Each of these options depends on the idea that separate, immaterial creatures have a higher degree of perfection than their material counterparts. ${ }^{38}$ Opposing the second alternative, Scotus introduces his argument exemplified by the case of good and bad, which leads to an

38 Iohannes Duns Scotus, Quaestiones super libros Metaphysicorum Aristotelis, lib. II, qq. 2-3, nn. 49-50 (ed. Etzkorn et al., 1997, p. 215): “Ad alias quinque rationes contra positionem respondetur quod vel concludunt quod cognoscimus de substantiis separatis 'quia sunt', vel in quantum sunt causae istorum inferiorum, non autem 'propter quid', cum effectus deficiens non sufficiat ut per ipsum cognoscatur 'quid est' causae. Vel aliter respondetur quod cognoscimus de eis quid non sunt, quia scilicet non sunt aliqua istorum inferiorum, propter hoc quod cognoscimus ipsas esse causas eccellentes respectu horum." 
interesting remark: given the epistemic preeminence of positive assertions, if the human intellect knows what an angel is not, then it must already know what an angel is. ${ }^{39}$ This asymmetrical statement, of course, supports the elimination scheme: introducing incompossibility, which is missing in the littera, Scotus's conclusion would be in fact better explained.

The same writing presents another interesting, similar case. In the questions on Metaphysics, IV, Scotus argues against the assertion that the truth-value of affirmative and negative propositions depends on the identity or diversity of the propositional extremes:

Responsio: hic est ordo: primo concipitur 'homo' et concipitur 'asinus'; secundo concipitur 'homo est homo' et 'asinus est asinus', et per has primas affirmativas, vel per altera istarum, concipitur negativa 'homo non est asinus'. Haec habentur, non concipiendo aliqua extrema aliorum generum. Post haec concipitur 'homo est unus', 'asinus est unus', ac post haec 'asinus est idem sibi' et 'homo sibi'. Deinde, quia 'unus' et 'unus homo' et 'asinus' sunt multa consequenter diversa, unde falsum est illud: 'veritas affirmativae est identitas extremorum, et negativae est diversitas'; immo magis est e converso, ut patet ex dictis. ${ }^{40}$

The negative sentence 'a man is not a donkey' is understood as dependent on two positive ones, namely 'a man is a man' and 'a donkey is a donkey'. However, the inference is not logically consequent: given in fact only the premises ' $\mathrm{A}$ is $\mathrm{A}$ ' and ' $\mathrm{B}$ is B', it is not correct to conclude that ' $\mathrm{A}$ is not $\mathrm{B}$ '. Moreover, Scotus suggests that each of the two premises is itself sufficient to generate the negative conclusion, thus reproducing the same pattern that we have already met in the case of bonum and malum. At the same time, however, the textual passage offers no explicit metaphysical explanation to uphold this conclusion, and yet a theoretical solution can once more be provided resorting to the concept of "incompossibility". It must be noted that in the commentary on the Metaphysics there are a few occurrences of the terms "repugnance", "compossibility" and "incompossibility" and still, even when

39 Iohannes Duns Scotus, Quaestiones super libros Metaphysicorum Aristotelis, lib. II, qq. 2-3, n. 55 (ed. Etzkorn et al., 1997, p. 217): "Et Philosophus IV huius: 'notior utique erit dictio quam opposita negatio.' Ergo si cognoscatur de angelo quid non est, oportet praecognoscere quid est."

40 Iohannes Duns Scotus, Quaestiones super libros Metaphysicorum Aristotelis, lib. IV, q. 2, n. 76 (ed. Etzkorn et al., 1997, p. 338). 
they are employed, they are never defined nor punctually analyzed. Keeping therefore the connotation of incompossibility as presented in the Ordinatio, we can fruitfully apply the elimination scheme to this case: 'If I know that 'a man is not a donkey', then I know that 'a man is a man' and that 'being a man is incompossible with being a donkey'. ${ }^{41}$ Both "man" and "donkey" are intrinsically possible natures, thus they satisfy the precondition to occur within a relation on incompossibility; they also cannot constitute a unitary thing nor produce a third element by interacting with each other, as the two special condition for incompossibility demand. Therefore, 'being a man' and 'being a donkey' are incompossible properties. The generalized scheme provides, hence, an explanation for at least two logically lacking examples in the commentary on the Metaphysics.

Independently from the littera, we can also note how the case of absolute perfections alone, exemplified by the case of "dog" and "rationality", can easily be extended to all the rational creatures, namely to all the beings that share that same perfection with God. If the consequence if I know that 'God is not a dog' then I know that 'God is rational' and 'being a dog is incompossible with being rational' holds, then similarly the consequences that we can obtain by substituting "God" with other predicables that stand for rational being, such as "man" or "angel", and "dog" with other predicables that stand for irrational beings, such as "donkey" or "stone", hold as well. This means that the eliminative strategy based on the account of absolute perfections can effectively be extended to some predicables over "God", and this extension is also sufficient to explain why a man is not a donkey.

The last cases to consider are the one in which the terms at stake are all outside the scope of absolute perfections, for instance that 'a dog is not a donkey', and the other in which they are all within it, such as 'a man is not an angel'. For both cases, the solution should depend only on the relation of incompossibility whose definition, relying purely on the natures corresponding to the terms, allows us to test each specific case.

In conclusion, even if we cannot provide an unmistakably evident textual application of the generalized form, its confutation is not obvious

${ }^{41}$ The generalised conditional was: if $\mathrm{I}$ know ' $\mathrm{A}$ is not B', then $\mathrm{I}$ know 'A is $\mathrm{C}$ and $\mathrm{A}$ is incompossible with $\mathrm{B}$ '. There is no assumption about the fact that $\mathrm{A}, \mathrm{B}, \mathrm{C}$ must be different terms, therefore the example about the man and the donkey, in which $\mathrm{A}$ and $\mathrm{C}$ are the same term, is not problematic. 
either and, what is more relevant, such a generalization is theoretically sound and provides an effective explanation for some unargued textual instances.

\section{The Second Strategy to Deal with Negation in Theology: An Attempted Algorithm}

Returning to the preliminary remarks from which we extrapolated the elimination scheme, Scotus adds other two paragraphs to support his asymmetrical account of negation in theology. The first one matches with the renowned expression negationes non summe amamus and is left without any further support or development. The explanation for this assertion lies in the conception of God as the highest, infinite end that every willing creature is naturally prone to love. ${ }^{42}$ To our aim, it is rather the remaining and last paragraph to be utterly relevant, because in this passage Scotus strives unequivocally to eliminate any negative theological knowledge:

Similiter etiam, aut negatio concipitur praecise, aut ut dicta de aliquo. Si praecise concipitur negatio, ut non-lapis, hoc aeque convenit nihilo sicut Deo, quia pura negatio dicitur de ente et de non-ente; igitur in hoc non magis intelligitur Deus quam nihil vel chimaera. Si intelligitur ut negatio dicta de aliquo, tunc quaero illum conceptum substratum de quo intelligitur ista negatio esse vera, aut erit conceptus affirmativus, aut negativus. Si est affirmativus, habetur propositum. Si negativus, quaero, ut prius: aut negatio concipitur praecise, aut ut dicta de aliquo. Si primo modo, hoc aeque convenit nihilo sicut Deo; si ut dicta de aliquo, sicut prius. Et quantumcumque procederetur in negationibus, vel non intelligeretur Deus magis quam nihil, vel stabitur in aliquo affirmativo conceptu qui est primus. ${ }^{43}$

42 Iohannes Duns Scotus, Tractatus de primo principio, cap. 4, n. 80 (ed. Porro, 2008, p. 194): "Sexta via ad propositum ex parte finis est talis: voluntas nostra potest omni fine finito aliquid maius appetere vel amare, sicut et intellectus intelligere. Et videtur inclinatio naturalis ad summe amandum bonum infinitum; nam inde arguitur inclinatio naturalis in voluntate ad aliquid, quia ex se sine habitu prompte et delectabiliter vult illud voluntas libera. Ita videtur quod experimur in amando bonum infinito: non videtur in alio perfecte quietari. Quomodo non illud naturaliter odiret, si esset oppositum sui obiecti, sicut naturaliter odit non esse."

${ }^{43}$ Iohannes Duns Scotus, Ordinatio, lib. I, d. 3, p. 1, qq. 1-2, n. 10 (ed. Balić et al., 1954, p. 5). 
The aim of this text is clear: it is epistemically futile to proceed negatively in the theological inquiry, because either (i) we do not say anything relevant about God, or (ii) we need to find a positive concept which is prior to any negative one we employ. Nevertheless, although the aim is clear, the argument is not. According to the text, there are two different ways to conceive negation: precisely and predicated about something else. The first case, exemplified by the expression "not-stone", matches the case of infinite terms, and Scotus states that knowing that 'God is a not-stone' is meaningless, since an infinite term can be predicated of anything but its positive counterpart: everything but a stone is a not-stone. Also, this conception of infinite terms as predicable even of non-existent or impossible beings such as the chimera can be traced back to the earliest works of the Subtilis, such as the commentaries on the Categories ${ }^{44}$ and on the Perihermeneias ${ }^{45}$ therefore, this first part of the argument is quite sound. What is much less clear is the second section. It must be noted at once that we could not find any other occurrence of the expression negatio dicta de aliquo in the critical editions of the Author's writing; therefore, such an expression might be a hapax legomenon. In order to suggest its meaning and given the fact that Scotus has already dismissed all the sentences such as 'God is a not-A' as epistemically vain, it is plausible that the remaining criticism will focus on phrasal negation, and therefore on sentences such as 'God is not a stone'. Given 'God is not A' and supposing its truth, Scotus asks whether the "substrate concept" of this kind of negation is affirmative or negative. If such a substrate is positive, then the negation will be positively grounded, as it was meant to prove, while if the substrate is negative, the procedure must be repeated from

${ }^{44}$ Iohannes Duns Scotus, Quaestiones super Praedicamenta Aristotelis, qq. 37-38, n. 20 (ed. Etzkorn et al., 1999, pp. 515-516): “[...]. Quod de negatione patet, quia licet illa dicatur de aliquo ente, ut 'non-homo' dicitur de asino, tamen secundum rationem qua contradicit homini non est ens nisi rationis. Per hoc patet quod licet contraria maneant, non exsistente intellectu, non oportet contradictoria manere secundum quod sunt contradictoria. Quia negado albi, prout contradicit albo, non est in nigro, quia ut contradicit, est dicibilis de ente et de non-ente."

45 Iohannes Duns Scotus, Quaestiones in Duos Libros Perihermeneias, pars I, q. 4 , n. 18 (Etzkorn \& alii, 2004, p. 162): “[...]. Negatio enim adveniens termino finito privat formam finitam significatam per terminum et relinquit ens indeterminatum ad quodcumque intellegibile et apprehensibile sub ratione qualitatis determinatae. Et ideo 'non-homo' convenit cuilibet, cui convenit qualitercumque ens naturae vel ens intellegibile, prout intelligitur sub privatione qualitatis finitae importatae per hoc nomen 'homo' [...]." 
the beginning, until a last positive element is reached. However, it is most unclear what this substrate is supposed to be: it might be either ' $A$ ' itself, since it would not make sense to further apply the algorithm ${ }^{46}$ to God or to the propositional subject, or another concept ' $\mathrm{B}$ ' on which 'A' depends. At any rate, we do not really understand how this application might be performed, since if we try to unfold it, we end up with several ambiguities. ${ }^{47}$ Another possible option would be to consider the negatio dicta de aliquo as something like this: 'B is not A' given that 'God is not A'. This choice grounds ' $A$ ' in a substrate which is independent from being predicated of God, yet again all of this is unsatisfactory when the procedure is applied.

${ }^{46}$ I choose the notion of "algorithm" because this argument can be outlined resorting to a diagram:

(1) If God is not A then either (i) "not A" is a negatio concipitur praecise or (ii) "not A" is a negatio dicta de aliquo.

(2) If (i) then stop, cvd.

(3) If (ii), either the substratum of "not A" is (iia) positive or (iib) negative.

(4) If (iia) then stop, cvd.

(5) If (iib), either the negation in the negative substratum is (iib, $\alpha$ ) a negatio concipitur praecise or (iib, $\beta$ ) a negatio dicta de aliquo.

(6) If (iib, $\alpha)$ then go to (2).

(7) If (iib, $\beta)$ then go to (3).

${ }^{47}$ Given 'God is not A', we must individuate a substrate concept, which might be ' $A$ '. (ia) If A is a positive substrate, the negation will not be positively grounded. This is because if we consider 'God is not a man', the fact that " $m a n$ " is positive does not reduce the negative form of knowledge expressed by the sentence to a positive one. (ib) If A is a negative substrate, then two cases are possible: $(\alpha)$ that $\mathrm{A}$ is a negatio praecise dicta and equals therefore not- $C$, so the sentence becomes 'God is not not- $C$ ', which again does not resolve the problem of eliminating the negative pole. $(\beta)$ that $\mathrm{A}$ is a negatio dicta de ali$q u o$, which is even worse, since we cannot find a grammatical way to express it: would it be 'God is not (is not C)'? We can also try to set a 'B' as the substrate concept. (iia) if $B$ is the positive substrate, it may mean that that ' $G o d$ is not A' becomes grounded in 'God is B', and in this case the elimination would occur. Yet it is unclear how ' $A$ ' and ' $B$ ' could be related: what kind of ' $B$ ' would allow us to ground 'God is not a man'? (iib) if $\mathrm{B}$ is the negative substrate, then two cases are possible: $(\alpha)$ that $\mathrm{B}$ is a negatio praecise dicta and it is then equal to non-C. Therefore, always supposing that ' $\mathrm{God}$ is not A' should be reduced to 'God is B', then the further passage would become 'God is not-C', and this would effectively satisfy the first argument about infinite negation. $(\beta)$ that $\mathrm{B}$ is a negatio dicta de aliquo. This case, again, hardly makes sense, because if a negatio dicta de aliquo is a propositional kind of negation, how can 'God is not B' be translated grammatically? 
Some light might be shed by Ordinatio, lib. I, d. 8 where Scotus resorts to a very similar argument, if not the same, but exploiting a different terminology:

Haec etiam est via Dionysii, quia quando per tertiam viam sive in tertio gradu, pervenerit ad illam 'cognitionem per remotionem', quaero an praecise cognoscatur ibi illa negatio, - et tunc non plus cognoscitur Deus quam chimaera, quia illa negatio est communis enti et non-enti; aut cognoscitur ibi aliquod positivum, cui attribuitur illa negatio,- - et tunc de illo positivo quaero quomodo conceptus eius habetur in intellectu: si per via causalitatis et eminentiae non habetur aliquis conceptus, prius causatus in intellectu, nihil omnino cognoscetur positivum cui attribuatur illa negatio. ${ }^{48}$

Negative theology is delegitimized once again; however, this case is much clearer: the "substrate concept" of the former quote is now replaced by an explicitly positive element to which the second kind of negation is applied. Also, instead of introducing a double-fold conception of negation as before, Scotus explains the way in which the positive grounding must be obtained by the human intellect, namely resorting to positive or superlative theology to the detriment of the negative one. Surely, the first argument presents a more interesting, formal structure and witnesses an attempt by Scotus to produce an abstract procedure to eliminate any negative form of knowledge about God. Its structure can easily be outlined in a schematic way as a diagram, yet the argumentation supporting it is unfortunately unclear and prone to misunderstandings. The second and last quoted text provides instead an argument which, despite being less formal and exclusively referred to theology, is favorable in terms of clarity and supports altogether the same eliminative claim that motivates the first one.

\section{Conclusion}

Scotus's writings display a variety of positions, four at least, that witness an asymmetricalist attitude towards negation. Moreover, a radical kind of asymmetricalism can be found in the Ordinatio, where Scotus is

${ }^{48}$ Iohannes Duns Scotus, Ordinatio, lib. I, d. 8, p. 1, q. 3, n. 73 (ed. Balić et al., 1956, p. 186). 
eager to deprive negative theology of any independency and pursues this aim by resorting to two main strategies: an elimination scheme and an elimination algorithm. The elimination scheme provides a way to reduce any negative epistemic proposition about God to a conjunction of two positive assertions. Resorting to his univocist account of predication, Scotus marks a few concepts that can be positively predicated about God, namely transcendentals, either "traditional" or absolute perfections and, most of all, the simple locution ens infinitum. It has also been shown how these positive predicables can occur in a relation of incompossibility, whose characterization is fundamental to assess the soundness of the scheme. Through a simple generalization on its terms, then, we managed to show how the scheme can be theoretically extended over the specific field of theological inquiry and how it can be employed to solve some logically unfounded arguments in the commentaries on the Metaphysics.

The second strategy, instead, has been proven less effective: despite the clear intention behind it, a significant part of the elimination algorithm, namely the regressive argument based on the conception of a negatio dicta de aliquo, is too ambiguous and barely comprehensible. Luckily, it has been possible to produce a different textual evidence which effectively presents a much more effective argument.

In conclusion, Scotus utilizes a remarkable amount of ink throughout his many writings to assess the preeminence of the positive on the negative, an effort which cannot be dismissed as secondary or accidental. The case of negative theology, specifically, intercepts and requires several of the most peculiar theoretical positions endorsed by the Subtilis, such as univocism and the redefinition of transcendental concepts. Furthermore, the theoretical consequences of his positions can be extended over the field of theological speculation, concurring to develop a general epistemic frame.

\section{References}

\section{Primary Sources}

Aristotle (1984). Prior Analytics. In: J. Barnes (ed.), The Complete Works of Aristotle-The Revised Oxford Translation. Vol. 1. Princeton: Princeton University Press. 
Aristotle (1984). Posterior Analytics. In: J. Barnes (ed.), The Complete Works of Aristotle-The Revised Oxford Translation. Vol. 1. Princeton: Princeton University Press.

Aristotle (1984). Metaphysics. In: J. Barnes (ed.), The Complete Works Of AristotleThe Revised Oxford Translation. Vol. 2. Princeton: Princeton University Press.

Duns Scotus, Iohannes (1950). Ordinatio I, d. 1-2. In: C. Balić, M. Bodewig, S. Bušelić, P. Čapkun-Delić, I. Jurić, I. Montalverne, S. Nanni, B. Pergamo, F. Prezioso, I. Reinhold, O. Schäfer (ed.), Iohannis Duns Scoti Opera Omnia. Vol. 2. Vatican City: Typis Polyglottis Vaticanis.

Duns Scotus, Iohannes (1954). Ordinatio I, d. 3. In: C. Balić, M. Bodewig, S. Bušelić, P. Čapkun-Delić, B. Hechich, I. Jurić, B. Korošak, L. Modrić, I. Montalverne, S. Nanni, B. Pergamo, F. Prezioso, I. Reinhold, O. Schäfer (ed.), Iohannis Duns Scoti Opera Omnia. Vol. 3. Vatican City: Typis Polyglottis Vaticanis.

Duns Scotus, Iohannes (1956). Ordinatio I, d. 4-10. In: C. Balić, M. Bodewig, S. Bušelić, P. Čapkun-Delić, B. Hechich, I. Jurić, B. Korošak, L. Modrić, S. Nanni, I. Reinhold. O. Schäfer (ed.), Iohannis Duns Scoti Opera omnia. Vol. 4. Vatican City: Typis Polyglottis Vaticanis.

Duns Scotus, Iohannes (1960). Lectura prologus I, d. 1-7. In: C. Balić, M. Bodewig, S. Bušelić, P. Čapkun-Delić, B. Hechich, I. Jurić, B. Korošak, L. Modrić, S. Nanni, I. Reinhold, O. Schäfer (ed.), Iohannis Duns Scoti Opera omnia. Vol. 16. Vatican City: Typis Polyglottis Vaticanis.

Duns Scotus, Iohannes (1963). Ordinatio I, d. 26-48. In: C. Balić, M. Bodewig, S. Bušelić, P. Čapkun-Delić, B. Hechich, I. Jurić, B. Korošak, L. Modrić, S. Nanni, I. Reinhold, O. Schäfer (ed.), Iohannis Duns Scoti Opera omnia. Vol. 6. Vatican City: Typis Polyglottis Vaticanis.

Duns Scotus, Iohannes (1966). Lectura I, d. 8-45. In: C. Balić, C. Barbarić, S. Bušelić, P. Čapkun-Delić, B. Hechich, I. Jurić, B. Korošak, L. Modrić, S. Nanni, S. Ruiz de Loizaga, C. Saco Alarcón, O. Schäfer (ed.), Iohannis Duns Scoti Opera omnia. Vol. 17. Vatican City: Typis Polyglottis Vaticanis.

Duns Scotus, Iohannes (1973). Ordinatio II, d. 1-3. In: C. Balić, C. Barbarić, S. Bušelić, B. Hechich, L. Modrić, S. Nanni, R. Rosini, S. Ruiz de Loizaga, C. Saco Alarcón (ed.), Iohannis Duns Scoti Opera omnia. Vol. 7. Vatican City: Typis Polyglottis Vaticanis.

Duns Scotus, Iohannes (1982). Lectura II, d. 1-6. In: L. Modrić, S. Bušelić, B. Hechich, I. Jurić, I. Percan, R. Rosini, S. Ruiz de Loizaga, C. Saco Alarcón (ed.), Iohannis Duns Scoti Opera omnia. Vol. 18. Vatican City: Typis Polyglottis Vaticanis. 
Duns Scotus, Iohannes (1997). Quaestiones super libros Metaphysicorum Aristotelis, lib. I-V. In: R. Andrews, G. Etzkorn, G. Gál, R. Green, F. Kelly, G. Marcil, T. Noone, R. Wood (ed.), B. Ioannes Duns Scoti Opera Philosophica. Vol. 3. St. Bonaventure, NY: The Franciscan Institute.

Duns Scotus, Iohannes (1999). Quaestiones super Praedicamenta Aristotelis. In: R. Andrews, G. Etzkorn, G. Gál, R. Green, T. Noone, R. Wood (ed.), B. Ioannis Duns Scoti Opera Philosophica. Vol. 1. St. Bonaventure, NY: The Franciscan Institute.

Duns Scotus, Iohannes (2004). Quaestiones in duos libros Perihermeneias Aristotelis. In: R. Andrews, O. Bychkov, S. Ebbesen, G. Gál, R. Green, T. Noone, R. Plevano, A. Traver (ed.), B. Ioannis Duns Scoti Opera philosophica. Vol. 2. St. Bonaventure, NY: Franciscan Institute; Washington, DC: The Catholic University of America Press.

Duns Scotus, Iohannes (2008). Tractatus de primo principio. Ed. P. Porro. Milan: Bompiani.

\section{Secondary Sources}

Alliney, G. (2012). Giovanni Duns Scoto_Introduzione al pensiero filosofico. Bari: Edizioni di pagina.

Biard, J. (2004). Duns Scot et l'infini dans la nature. In: O. Boulnois, E. Karger, J.-L. Solère \& G. Sondag (eds.), Duns Scot à Paris, 1302-2002. Actes du colloque de Paris, 2-4 septembre 2002 (pp. 387-405). Textes et études du Moyen Âge 26. Turnhout: Brepols.

Cezar, C.R. (2008). Teologia positiva e teologia negativa em Duns Scotus. In: L.A. de Boni (ed.), João Duns Scotus (1308-2008): homenagem de scotistas lusófonos (pp. 186-197). Porto Alegre: EST Edições; Bragança Paulista: EDUSF.

Duba, W.O. (2005). Aristotelian Traditions in Franciscan Thought: Matter and Potency according to Scotus and Auriol. In: I. Taifacos (ed.), The Origins of European Scholarship: The Cyprus Millennium International Conference (pp. 147-61). Stuttgart: Franz Steiner Verlag.

Dumont, S.D. (1998). Scotus's Doctrine of Univocity and the Medieval Tradition of Metaphysics. In: J. A. Aertsen, A. Speer (eds.), Was ist Philosophie im Mittelalter? Qu'est-ce que la philosophie au Moyen Âge? What is Philosophy in the Middle Ages? Akten des X. Internationalen Kongresses für mittelalterliche Philosophie der Société Internationale pour l'Étude de la Philosophie 
Médiévale, 25. bis 30. August 1997 in Erfurt (pp. 193-212). Berlin-New York: de Gruyter.

Flores, J.C. (2000). Accidental and Essential Causality in John Duns Scotus' Treatise "On the First Principle". Recherches de Théologie et Philosophie médiévales, 67, 96-113.

Henninger, M.G. (1989). Relations: Medieval Theories 1250-1325. Oxford: Clarendon Press.

Hoffmann, T. (2013). The Quaestiones De anima and the Genesis of Duns Scotus' Doctrine of Univocity of Being. In: J.-M. Counet, R. Friedman (eds.), Medieval Perspectives on Aristotle's De anima (pp. 101-120). Leuven: Peeters.

Horn, L. (2001). A Natural History of Negation (2nd ed.). USA: CSLI Publications.

King, P. (2001). Duns Scotus on Possibilities, Power and the Possible. In: T. Buchheim, C.H. Kneepkens, K. Lorenz (eds.), Potentialität und Possibilität: Modalaussangen in der Geschichte der Metaphysik (pp. 175-199). Stuttgart: Frommann, Holzboog.

King, P. (2003). Scotus on Metaphysics. In: T. Williams (ed.), The Cambridge Companion to Duns Scotus (pp. 15-68). Cambridge: Cambridge University Press.

Mann, W.E. (2003). Duns Scotus on Natural and Supernatural Knowledge of God. In: T. Williams (ed.), The Cambridge Companion to Duns Scotus (pp. 238262). Cambridge: Cambridge University Press.

Marenbon, J. (2016). Relations and the Historiography of Medieval Philosophy. British Journal of the History of Philosophy, 24 (3), 387-404.

Mondadori, F. (2004). The Independence of the Possible According to Scotus. In: O. Boulnois, E. Karger, J.-L. Solère, G. Sondag (eds.), Duns Scot à Paris, 1302-2002. Actes du colloque de Paris, 2-4 septembre 2002 (pp. 313-374). Turnhout: Brepols.

Mugnai, M. (2016). Ontology and Logic: The Case of Scholastic and Late-Scholastic Theory of Relations. British Journal of the History of Philosophy, 24 (3), 532-553.

Ninci, M. (1995). Il concetto di essere e la teologia negativa: Duns Scoto ed Enrico di Gand di fronte allo Ps.-Dionigi. In: L. Sileo (ed.), Via Scoti: Methodologia ad mentem Joannis Duns Scoti. Atti del Congresso Scotistico Internazionale Roma, 9-11 marzo 1993. Vol. 2 (pp. 681-737). Roma: Edizioni Antonianum.

Normore, C.G. (2003). Duns Scotus's Modal Theory. In: T. Williams (ed.), The Cambridge Companion to Duns Scotus (pp. 129-160). Cambridge: Cambridge University Press. 
Pasnau, R. (2003). Cognition. In: T. Williams (ed.), The Cambridge Companion to Duns Scotus (pp. 285-311). Cambridge: Cambridge University Press.

Pasnau, R. (2011). Metaphysical Themes 1274-1671. Oxford: Clarendon Press.

Pini, G. (2005). Univocity in Scotus' Quaestiones super Metaphysicam: The Solution to a Riddle. Medioevo, 30, 69-110.

Ross, F., Bates T. (2003). Duns Scotus on Natural Theology. In: T. Williams (ed.), The Cambridge Companion to Duns Scotus (pp. 193-238). Cambridge: Cambridge University Press.

Schönberger, R. (1996). Negationes non summe amamus. Duns Scotus'A Auseinandersetzung mit der negativen Theologie. In: L. Honnefelder, R. Wood, M. Dreyer (eds.), John Duns Scotus: Metaphysics and Ethics (pp. 475-496). Leiden: Brill.

Sondag, G. (2005). Jean Duns Scot sur l'infini extensive et l'infini intensif. Revue thomiste, 105, 111-122.

\begin{abstract}
The aim of this paper is to detect and assess some parasitic aspects that characterize John Duns Scotus's account of negation, with a major focus on epistemology and theology. The first paragraph introduces the concepts of asymmetricalism or negation parasitism and traces the occurrence of four asymmetricalist theses in the Author's production. The second paragraph presents and analyzes a first strategy to dismiss negative theology through an elimination scheme, namely a conditional which reduces negative epistemic propositions to positive ones. The third section attempts a generalization of such a scheme to make it suitable for any kind of negative knowledge foreign to the theological context. The fourth and last paragraph presents a different and more problematic eliminative strategy for negative theology and deals with the issues that arise from it.
\end{abstract}

